\title{
Neonatal Prognosis and Outcomes in Adolescent Pregnancies
}

\author{
Adölesan Gebeliklerin Neonatal Prognoz ve Sonuçları \\ ๑ Burcu Cebeci, ๑ Sultan Kavuncuoglu*, ๑ Tugba Erener Ercan, ๑ Zeynep Eras ${ }^{\star \star}$, \\ (-) Merih Cetinkaya
}

University of Health Science Turkey, Kanuni Sultan Suleyman Training and Research Hospital, Clinic of Neonatology, Istanbul, Turkey

* University of Health Science Turkey, Kanuni Sultan Suleyman Training and Research Hospital, Clinic of Pediatrics, Istanbul, Turkey

** University of Health Science Turkey, Zekai Tahir Burak Maternity and Children's Education Hospital, Clinic of Developmental Behavioral Pediatrics Unit, Ankara, Turkey

\section{Abstract}

\begin{abstract}
Aim: The study aims to determine features, morbidities and mortality of adolescent pregnants and their hospitalized newborns in the neonatal period.
\end{abstract}

Methods: Six hundred forty-one adolescent pregnants were enrolled and compared to 309 non-adolescent pregnants. Demographic characteristics of mothers and complications of delivery, demographic characteristics of newborns, morbidities, and mortality of infants admitted to hospital during neonatal period were recorded.

Results: The mean age of adolescent and non-adolescent pregnants were $17.2 \pm 0.8$ and $27.0 \pm 4.3$ years, respectively. Education levels, being housewife, extramarital birth-giving, cesarean section rate, and twin pregnancy were higher in adolescent pregnants. The mean height, head circumference, and weight of newborns in adolescent pregnants were significantly lower. Even though neonatal mortality was similar in both pregnants, early neonatal morbidities were more common in adolescent pregnants. Duration and rate of hospitalization, and morbidities causing hospitalization during the neonatal period were similar in the babies of both pregnants. Among babies admitted to the neonatal intensive care unit, mortality rates were higher in babies born to non-adolescent mothers.

Conclusion: Worse neonatal outcome of babies born to adolescent pregnants, and higher mortality in the neonatal period in non-adolescent pregnants were found. But characteristics and morbidities of babies hospitalized in the neonatal period were similar in both groups.

Keywords: Adolescent pregnancy, hospitalization, neonatal morbidity, neonatal mortality, newborn
Amaç: Çalışmamızın amacı, adolesan gebelerin ve yenidoğan döneminde hastaneye yatırılan bebeklerinin özelliklerini, morbidite ve mortalitelerini araştırmaktır.

Yöntemler: Çalışmaya 641 adolesan ve 309 adolesan olmayan gebe dahil edildi. Anne ve bebeklerin demografik özellikleri, doğum komplikasyonları, yenidoğan döneminde hastaneye yatırılan bebeklerinin morbidite ve mortaliteleri kaydedildi.

Bulgular: Adolesan olan ve olmayan gebelerin ortalama yaşı sırasıyla $17,2 \pm 0,8$ ve $27,0 \pm 4,3$ yıldı. Adolesan gebelerde eğitim düzeyleri, ev hanımı olma oranı, evlilik dışı doğum oranı, sezaryen doğum oranı ve ikiz gebelik oranı daha yüksekti. Adölesan anne bebeklerinde ortalama boy, baş çevresi ve ağırlık anlamlı düzeyde daha düşüktü. Neonatal mortalite her iki grupta benzer saptanmışken, erken neonatal morbiditeler adolesan gebe bebeklerinde daha sık saptanmıştı. Hastane yatış oranı, süresi ve yatışa neden olan yenidoğan dönemi morbiditeleri her iki grup bebeklerinde benzerdi. Yenidoğan yoğun bakıma yatan bebekler arasında, mortalite kontrol grubunda daha yüksekti.

Sonuç: Çalışmamızda adolesan anne bebeklerinde doğum özellikleri daha düşük saptanmışken, hastaneye yatan adolesan olmayan anne bebeklerinde ise neonatal mortalite yüksek bulunmuştur. Yenidoğan döneminde yatırılan bebeklerin özellikleri ve morbiditeleri her iki grupta benzer saptanmıştır.

Anahtar Sözcükler: Adolesan gebelik, hastane yatışı, neonatal morbidite, neonatal mortalite, yenidoğan
Address for Correspondence/Yazışma Adresi: Burcu Cebeci, Kanuni Sultan Suleyman Training and Research Hospital, Clinic of Neonatology, Istanbul, Turkey Phone: +90 2124955808 E-mail: drburcucebeci@hotmail.com ORCID: orcid.org/0000-0003-1886-8126 Received/Geliş Tarihi: 23.09.2020 Accepted/Kabul Tarihi: 24.12.2020
${ }^{\circ}$ Copyright 2021 by The Medical Bulletin of istanbul Haseki Training and Research Hospital The Medical Bulletin of Haseki published by Galenos Yayınevi. ${ }^{\circledR}$ Telif Hakkı 2021 istanbul Haseki Eğitim ve Araştırma Hastanesi Haseki Tıp Bülteni, Galenos Yayınevi tarafından yayınlanmıştır. 


\section{Introduction}

Adolescent period involves a frame of time when the individual goes through biological, psychological and social changes. As the definition of World Health Organization states, it is a nine years period between ages of 10-19. Because of the biological immaturity, being an adolescent pregnant is an important factor which poses a risk for both the mother and the newborn (1). Becoming pregnant during adolescence can greatly alter young women's life prospects and those of their children. Complications of pregnancy and childbirth are the second leading cause of death among 15-19-year-old women (2). Malnutrition, smoking and alcohol use, emotional stres and suboptimal prenatal care are observed more in adolescents $(3,4)$. Stillbirth, death within the first week and month are higher in newborns born to adolescent mothers compared to mothers between ages of 20-29 years and the risk increases as the age of the mother decreases. Although preterm birth, low birth weight and asphyxia rates are higher in adolescent mothers, all of which increase risks for the infants, morbidities and mortality of the babies born to adolescent pregnants who needs to be hospitalized during neonatal period have not been clearly identified in our population.

The aim of our study was to determine the features and problems related to adolescent pregnancies for the mothers and the newborns during delivery and their newborns having problems during neonatal period in our country.

\section{Methods}

\section{Study Population}

The single center, retrospective, observational, cohort study protocol was approved by the local Ethics Committee. All procedures performed in studies involving human participants were in accordance with the ethical standards of the institutional and/or national research committee and with the 1964 Helsinki declaration and its later amendments or comparable ethical standards. This article does not contain any studies with animals performed by any of the authors. Ethical clearance was obtained from the Ethics Committee of the Bakirkoy Maternity and Children Hospital. 950 pregnants having no missing data of patient files and whose babies were followed up in neonatal period were enrolled to our study during two years in our hospital. Pregnants below 15 years and above 35 years, patients with missing data, pregnants with in utero ex fetus and babies who could not be followed up in our hospital during neonatal period were excluded from the study. The adolescent mothers consisted of pregnants aged between 15 and 19 years and the non-adolescent pregnants consisted of mothers aged between 20 and 35 years. Six hundred and fortyone adolescent pregnants and three hundred and nine non-adolescent pregnants were enrolled to the study. Patient files and hospital database records were provided via newborn database by the researcher.

\section{Maternal Characteristics}

Maternal charactetristics included age, marital status, duration of marriage, consanguineous marriages, smoking history, occupation, educational status, mode of delivery, cesarean indication, and obstertric complication.

\section{Neonatal Features}

Last menstruation date or new Ballard score with ultrasound were used to determine the gestational age and preterm delivery (gestation <37 weeks). Neonatal characteristics included gender, APGAR score $\left(1^{\text {st }}\right.$ and $5^{\text {th }}$ minutes), low $1^{\text {st }}$ and $5^{\text {th }}$ minutes APGAR score (less $<7$ ), birth weight (gram), low birth weight (less than 2.500 $\mathrm{g}$ ), very low birth weight (less than $1.500 \mathrm{~g}$ ), birth height $(\mathrm{cm})$, head circumference $(\mathrm{cm})$, congenital abnormalities, intrauterine growth retardation (IUGR), the presence of neonatal respiratory problems respiratory distress syndrome (RDS) and/or transient tachyphnea of newborn (TTN), meconium aspiration syndrome, hypoglycemia, Rh incompatibility, polycythemia, hyperbilirubinemia, and presence of resuscitation.

\section{Features of Newborns Admitted to Hospital}

Rate of prematurity, presence of accompanying congenital malformation, duration of hospitalization, level of hospitalization, ventilatory support, duration of total parenteral nutrition, the reasons for hospitalization, mortality rates during hospitalization of babies in neonatal period were recorded.

\section{Data analysis}

The analyses were performed by using the SPSS software (Statistical Package for the Social Sciences, version 20.0, SPSS Inc, Chicago Illinois, USA). Data are expressed as mean \pm standard deviation. Parametric variables were compared with student's t-test between dependent variables and with Mann-Whitney $U$ test between undependent variables. Categorical variables were compaired by using Pearson's chi-square test and Fisher's exact test was used parameters that were not normally distributed. The results were evaluated with a confidence interval of $95 \%$ and a significance level of $p<0.05$.

\section{Results}

\section{Maternal Outcomes}

Demographic characteristics of adolescent and nonadolescent pregnants were given in Table 1. The cesarean rate was significantly higher in the adolescent pregnants 
compared to non-adolescent pregnants $(52.9 \%$ and $42.7 \% ; p=0.003)$. The most common cesarean indications were fetal distress, cephalopelvic disproportion and breech presentation in adolescent pregnants, however the most common indication was a previous cesarean section in the non-adolescent pregnants. 529 (82.5\%) of the adolescent pregnants did not have any obstetric complications and the most common reason was bleeding among 112 $(17.5 \%)$ of adolescent pregnants having complication. Whereas in non-adolescent pregnants; 235 pregnancies (76\%) did not develop obstetric complications and 74 (24\%) of the pregnants had bleeding as the most common complication. Preeclampsia rates were also similar $(2.2 \%$ vs $3.9 \%, p=0.133$, respectively). While $96(15 \%)$ of the adolescents had premature birth, $53(17.2 \%)$ of the nonadolescent pregnants had premature birth $(p=0.388)$. Pregnant women in the adolescent age group stayed $1.9 \pm 1.2$ days in the hospital, while the hospitalization duration of the pregnant women in the non-adolescent group was $1.8 \pm 1.2$ days $(p=0.19)$.

\section{Neonatal Outcomes}

Six hundred and sixty-six babies were delievered from 641 adolescent women, 313 babies were delivered from 309 non-adolescent women. One hundred and six (16.1\%) of the babies born to adolescent mothers had a birth weight below $2500 \mathrm{~g}$, while 31 (9.9\%) of the infants born to non-adolescent mothers had a birth weight below 2500 $g(p=0.01) .18(2.7 \%)$ of the babies born to adolescent mothers had a birth weight below $1500 \mathrm{~g}$, while 5 (9.9\%) of the infants born to non-adolescent mothers had a birth weight below $1500 \mathrm{~g}(\mathrm{p}=0.281)$.

There were no congenital anomalies of any system among $614(92.2 \%)$ of the infants born to adolescent mothers, and 270 (86.3\%) of the infants born to nonadolescent mothers, however the genitourinary and central nervous system anomalies were significantly higher in the babies of the non-adolescent group ( $p=0.01$ and $p=0.03$, respectively). Demographic characteristics of newborns born to adolescent and non-adolescent mothers are given in Table 2 .

Four hundred and twent one (63.2\%) of babies born to adolescent mother had no any problem while $242(77.3 \%)$ of the babies born to non-adolescent pregnants were all well during neonatal period. Early neonatal morbidities are summarized in Table 3. Among the morbidities resulted with hospitalization; meconium aspiration syndrome (MAS), respiratory distress syndrome, and hypogylycemia were significantly higher in the adolescent group compared to the non-adolescent group. The rate of resuscitation was $12.5 \%(n=83)$ in babies born to adolescent mother whereas $9.3 \%(n=29)$ in babies born to non-adolescent mothers $(p=0.143)$.

\begin{tabular}{|c|c|c|c|}
\hline & $\begin{array}{l}\text { Adolescent } \\
\text { pregnant } \\
(\mathrm{n}=641)\end{array}$ & $\begin{array}{l}\text { Non-adolescent } \\
\text { pregnant } \\
(\mathrm{n}=309)\end{array}$ & p \\
\hline $\begin{array}{l}\text { Age (year) } \\
(\text { mean } \pm S D)\end{array}$ & $17.2 \pm 0.8$ & $27.0 \pm 4.3$ & $<0.001$ \\
\hline Married (\%) & $93.3 \%$ & $99.7 \%$ & $<0.001$ \\
\hline $\begin{array}{l}\text { Duration of marriage } \\
\text { (years) (mean } \pm S D)\end{array}$ & $1.6 \pm 0.9$ & $6.1 \pm 4.1$ & $<0.001$ \\
\hline $\begin{array}{l}\text { Consanguineous } \\
\text { marriage (\%) }\end{array}$ & $9.7 \%$ & $13.3 \%$ & 0.09 \\
\hline Smoker (\%) & $0.9 \%$ & $0.6 \%$ & 0.488 \\
\hline $\begin{array}{l}\text { Unemployment rate } \\
(\%)\end{array}$ & $99.5 \%$ & $93.3 \%$ & $<0.001$ \\
\hline Education level (\%) & $\begin{array}{l}\text { 16.7\% Illiterate } \\
42.3 \% \text { PSG } \\
34.2 \% \text { SSG } \\
6.7 \% \text { HSG }\end{array}$ & $\begin{array}{l}\text { 20.6\% Illiterate } \\
\text { 44\% PSG } \\
17.2 \% \text { SSG } \\
14.6 \% \text { HSG } \\
3.9 \% \text { Bachelor }\end{array}$ & $<0.001$ \\
\hline
\end{tabular}

PSG: Primary school graduate, SSG: Secondary school graduate, HSG: High school graduate

\begin{tabular}{|l|l|l|l|}
\hline $\begin{array}{l}\text { Table 2. Neonatal characteristics of newborns born to the } \\
\text { adolescent and non-adolescent mothers }\end{array}$ \\
\hline & $\begin{array}{l}\text { Adolescent } \\
\text { mothers' babies } \\
\text { (n=666) }\end{array}$ & $\begin{array}{l}\text { Non- } \\
\text { adolescent } \\
\text { mothers' } \\
\text { babies } \\
\text { (n=313) }\end{array}$ & p \\
\hline Gestational week (week) & $37.8 \pm 2.3$ & $37.7 \pm 2.1$ & 0.526 \\
\hline Gender (male) & $50.2 \%$ & $49.2 \%$ & 0.782 \\
\hline $1^{\text {st }}$ min. Low APGAR (<7) & $19.7 \%$ & $5.1 \%$ & $<0.001$ \\
\hline $5^{\text {th }}$ min. Low APGAR (<7) & $1.1 \%$ & $0.3 \%$ & 0.216 \\
\hline Birth weight (gr) & $3033 \pm 660$ & $3202 \pm 587$ & $<0.001$ \\
\hline Birth height (cm) & $49.2 \pm 3.5$ & $49.9 \pm 2.7$ & 0.002 \\
\hline $\begin{array}{l}\text { Birth head circumference } \\
\text { (cm) }\end{array}$ & $34 \pm 2.1$ & $34.7 \pm 2.1$ & $<0.001$ \\
\hline
\end{tabular}

\section{Outcomes of Newborns Admitted to Hospital}

In adolescent group, one hundred and twelve of six hundred and sixty six (17\%) babies were hospitalized in the neonatal period however only fourty of three hundred and thirteen (13\%) babies were hospitalized in the non-adolescent mothers $(p=0.104)$. The reasons of hospitalization of babies admitted to neonatal intensive care unit are given in Table 4. Hospitalization due to MAS was significantly higher in the babies born to adolescent mothers. Among the hospitalized babies; twenty-nine (25.9\%) of 112 babies born to adolescent mothers were premature while $9(22.5 \%)$ babies were premature in nonadolescent mothers $(p=0.671)$. And $13(11 \%)$ babies in the adolescent group and $3(7 \%)$ babies in the control group had no any congenital malformation ( $p=0.962)$. While the hospitalized infants born to adolescent mother had an 


\begin{tabular}{|l|l|l|l|l|}
\hline \multicolumn{5}{|l|}{$\begin{array}{l}\text { Table 3. Neonatal morbidities in newborns born to adolescent } \\
\text { and non-adolescent pregnants }\end{array}$} \\
\hline & $\begin{array}{l}\text { Adolescent } \\
\text { pregnants' } \\
\text { babies } \\
\text { (n=666) }\end{array}$ & $\begin{array}{l}\text { Non- } \\
\text { adolescent } \\
\text { pregnants' } \\
\text { babies } \\
\text { (n=313) }\end{array}$ & OR (95\% Cl) & p \\
\hline $\begin{array}{l}\text { Respiratory } \\
\text { problems }\end{array}$ & $74(11.1 \%)$ & $14(4.5 \%)$ & $\begin{array}{l}0.375 \\
(0.208-0.674)\end{array}$ & 0.001 \\
\hline MAS & $52(7.8 \%)$ & $9(2.9 \%)$ & $\begin{array}{l}0.350 \\
(0.170-0.719)\end{array}$ & 0.003 \\
\hline Hypoglycemia & $44(6.6 \%)$ & $10(3.2 \%)$ & $\begin{array}{l}0.467 \\
(0.232-0.940)\end{array}$ & 0.029 \\
\hline Rh incompatibility & $34(5.1 \%)$ & $23(7.3 \%)$ & $\begin{array}{l}1.474 \\
(0.853-2.548)\end{array}$ & 0.162 \\
\hline IUGR & $17(2.6 \%)$ & $8(2.6 \%)$ & $\begin{array}{l}1.001 \\
(0.427-2.346)\end{array}$ & 0.998 \\
\hline Polycythemia & $8(1.2 \%)$ & $3(1 \%)$ & $\begin{array}{l}0.796 \\
(0.210-3.021)\end{array}$ & 0.737 \\
\hline Hyperbilirubinemia & $8(1.2 \%)$ & $2(0.6 \%)$ & $\begin{array}{l}0.529 \\
(0.112-2.505)\end{array}$ & 0.415 \\
\hline MAS: Meconium aspiration syndrome, IUGR: Intrauterine growth retardation \\
\hline
\end{tabular}

Table 4. Reasons of hospitalization and morbidities of babies admitted to the neonatal intensive care unit

\begin{tabular}{|l|l|l|l|}
\hline & $\begin{array}{l}\text { Adolescent } \\
\text { pregnants' } \\
\text { babies (n=112) }\end{array}$ & $\begin{array}{l}\text { Non- } \\
\text { adolescent } \\
\text { pregnants' } \\
\text { babies (n=40) }\end{array}$ & p \\
\hline Hypogylcemia & $12(10.7 \%)$ & $2(5 \%)$ & 0.232 \\
\hline TTN & $20(17.9 \%)$ & $6(15 \%)$ & 0.680 \\
\hline MAS & $10(8.9 \%)$ & 0 & 0.042 \\
\hline Hyperbilirubinemia & $44(39.3 \%)$ & $14(35 \%)$ & 0.632 \\
\hline Septicemia & $27(24.1 \%)$ & $15(37.5 \%)$ & 0.104 \\
\hline $\begin{array}{l}\text { Respiratory Distress } \\
\text { Syndrome }\end{array}$ & $12(10.7 \%)$ & $4(10 \%)$ & 0.583 \\
\hline $\begin{array}{l}\text { Bronchopulmonary } \\
\text { Dysplasia }\end{array}$ & $3(2.7 \%)$ & $1(2.5 \%)$ & 0.717 \\
\hline $\begin{array}{l}\text { Retinopathy of } \\
\text { Prematurity }\end{array}$ & $5(4.5 \%)$ & $2(5 \%)$ & 0.592 \\
\hline $\begin{array}{l}\text { Necrotizing } \\
\text { Enterocolitis }\end{array}$ & $2(1.8 \%)$ & $1(2.5)$ & 0.603 \\
\hline $\begin{array}{l}\text { Intraventricular } \\
\text { hemorrage }\end{array}$ & $5(4.5 \%)$ & $2(5 \%)$ & 0.592 \\
\hline TTN: Transient tachypnea of newborn, MAS: Meconium aspiration syndrome \\
\hline
\end{tabular}

average of 9.1 days, the mean hospitalization period of the infants was 8.2 days in the non-adolescent mothers. $(p=0.707)$. When the level of hospitalization was evaluated; $80(71.4 \%)$ of the babies born to adolescent mothers were in the first level, 18 (16.1\%) were in the second level and $14(12.5 \%)$ were in the third level intensive care unit whereas $28(70 \%)$ of the babies born to non-adolescent mothers were in the first level, 6 (15\%) were in the second level and 6 (15\%) were in the third level intensive care unit. There was no significant difference between the groups in terms of hospitalization level $(p=0.919)$. Twelve(10.7\%) of the hospitalized babies born to adolescent mothers needed mechanical ventilation support while $4(10 \%)$ of the infants were needed for the mechanical ventilation support in the control group. While the infants born to adolescent mothers who connected to the ventilator needed an average of $8.1 \pm 9.2$ days of ventilator support during their hospitalization, it was observed that in, the infants born to non-adolescent mothers spent $14.2 \pm 8.0$ days of ventilator support $(p=0.261)$. While $27(24.1 \%)$ of the hospitalized adolescent mothers needed total parenteral nutrition support for 10.5 days during the hospitalization period, 9 (22.5\%) of their babies needed an average of 10.3 days during their hospitalization. 27 $(24.1 \%)$ of the infants born to adolescent mother were fed with total parenteral nutrition $t$ for 10.5 days while $9(22.5 \%)$ of the babies born to non-adolescent mothers needed an average of 10.3 days of total parenteral nutrion during hospitalization ( $p=0.949$ ).

Three $(2.7 \%)$ infants who were hospitalized in the adolescent group and two (5\%) of the infants born to nonadolescent mothers died during hospitalization. Mortality rate among hospitalized infants born to non-adolescent mothers was significantly higher $(p=0.002)$.

\section{Discussion}

We evaluated the outcomes of babies born to adolescent mother who gave birth in our hospital which is one of the important tertiary referral hospital in our country. Babies born to adolescent mother had worse fetal outcome during antenatal period, despite the results of those hospitalized babies in the first 28-day period were similar compared to babies born to non-adolescent mothers. Although there are studies examining the results of adolescent pregnancies in our country, our study is the first study that compared the babies born to adolescent pregnant with the non-adolescent pregnants who were hospitalized in the neonatal period.

Adolescent pregnancy is usually an unintended pregnancy mostly seen among women who have an unsteady lifesytle and were unmarried in the western countries. In our country, adolescent pregnancy is usually seen as a result of early marriage especially in low socioeconomic groups. However, these pregnancies are mostly intended and planned according to the expectations of the families of the parents. In our study, the rate of extramarital pregnancy in adolescents was $5.5 \%$ and was significantly higher than non-adolescent pregnants. However, this rate was found to be lower compared to other studies (5-7). According to the World Health Organization, low level of education and living in rural areas increase the incidence 
of adolescent pregnancy and childbirth. In our study, the educational level of adolescent pregnant women was significantly lower $(p<0.001)$ compared to adult pregnant women. Similarly, there are studies reporting low education level in the adolescent pregnant women in the literature $(6,8)$. A large proportion of pregnant women in our country were married and have a regular daily life. Drug use or alcoholic beverage consumption were almost never present.

Gestational week and birth weight are important in neonatal morbidity and mortality. In our study, there was no difference in the rate of preterm birth in adolescent and adult group. The findings of Suparp Thaitha and Thato (9), Raatikain et al. (10) and Chen et al. (5) were in agreement with our study. However, in many other studies; the rates of preterm delivery were found to be higher in the adolescent pregnants compared to the non-adolescent pregnants $(6-8,11-13)$. In our country, according to the Demographic and Health Survey of Turkey; the rate of low birth weight babies was found to be $12.2 \%$ in born to mother $<20$ year, $11.9 \%$ in born to mother between 20-34 years, and $11.8 \%$ in born to mother between $35-49$ years (14). In the present study, birth weights of infants born to adolescent mothers were found to be significantly lower compared to infants born to adult mothers. In another study conducted in our hospital, Sultan Kavuncuoğlu et al. (15) reported the ratio of low birthweight as $9 \%$. There are several studies reporting similar results to our study $(7,10,12,13)$. However, some of the studies reported no significant difference between the groups $(5,9)$. Similar to the study conducted by Shrim et al. (13) in our study, the rate of low APGAR scores ( $1^{\text {st }}$ minute) was found to be significantly higher in the adolescent pregnants compared to the non-adolescent pregnants. Chen et al. (5) and Kongnyuy et al. (6) reported lower $5^{\text {th }}$ minute APGAR scores in the babies of adolescent mothers compared to those of the non-adolescent mothers However, Thaithae and Thato (9), Rasheed et al. (10) and Rahheed et al. (8) showed no statistically significant difference in terms of $1^{\text {st }}$ and $5^{\text {th }}$ minute APGAR scores between the adolescent and the non-adolescent pregnants.

In our study, hospitalization rates and average hospitalization day among newborns did not differ between the groups $(p=0.104$ and $p=0.707)$. There are varying findings in the literature. Rasheed et al. (10), found no significant difference among hospitalization rates while Shrum et al. (13) and Rasheed et al. (9) reported higher hospitalization rates in the adolescent group $(p<0.001$ and $p<0.01$, respectively).

There were some limitations of the study. Our study was designed as single center and retrospective. And also this study reported the short duration of follow-up to identify morbidities and mortality, as some outcomes may take a longer duration to develop. The findings from our study hopefully lend itself to form a template for further and prospective, multicentre clinical study.

\section{Conclusion}

Our results showed that $1^{\text {st }}$ minute Apgar scores and birth weight, height and head circumference were lower and cesarean delivery rate, early neonatal morbidities (respiratory distress, MAS, hypoglycemia) and hospitalization rates were higher in the newborns born to the adolescent mothers compared to the nonadolescent mothers. Prematurity rate was similar in both groups, and among hospitalized patients, there was no difference in the duration of hospitalization when the level of hospitalization and the etiologies were taken into account. Our study is the first comprehensive study including adolescent pregnants and outcomes of their babies in neonatal period. Also, there is still urgent need of multi-centered studies evaluating long-term outcomes and morbidities related to growth, development and neurodevelopmental prognosis of these infants.

\section{Acknowledgments}

We would like to express our gratitude to the patients and their parents whose records were used in this study, without whom this research would not be possible.

\section{Authorship Contributions}

Concept: B.C., Design: B.C., M.Ç., S.K., Data Collection or Processing: BC., Analysis or Interpretation: B.C., T.E.E., Z.E., M.Ç., S.K., Literature Search: B.C., Writing: B.C.

Conflict of Interest: No conflict of interest was declared by the authors.

Financial Disclosure: The authors declared that this study received no financial support

\section{References}

1. Beverly Bowers. Prenatal, Antenatal, Postpartal Risk Factors. In: Carole Kenner, Judy Wright Lott, editor. Comprehensive Neonatal Care: An Interdisciplinary Approach. Missouri: Elsevier; 2007. p. 651

2. World Health Organization, Mortality, morbidity and disability in adolescence, 2020. Available from: https://apps.who.int/ iris/bitstream/handle/10665/332070/9789240005105-eng. pdf Accessed June 28, 2020.

3. Stevens-Simon C, McAnarney ER. Adolescent pregnancy. Gestational weight gain and maternal and infant outcomes. Am J Dis Child 1992;146:1359-64.

4. Hoekelman RA. Teenage pregnancy-one of our nation's most challenging dilemmas. Pediatr Ann 1993;22:81-2.

5. Chen XK, Wen SW, Fleming N, Demissie K, Rhoads GG, Walker $\mathrm{M}$. Teenage pregnancy and adverse birth outcomes: a large 
population based retrospective cohort study. Int J Epidemiol 2007;36:368-73.

6. Kongnyuy EJ, Nana PN, Fomulu N, Wiysonge SC, Kouam L, Doh AS. Adverse perinatal outcomes of adolescent pregnancies in Cameroon. Matern Child Health J 2008;12:149-54.

7. Kuo CP, Lee SH, Wu WY, Liao WC, Lin SJ, Lee MC. Birth outcomes and risk factors in adolescent pregnancies: results of a Taiwanese national survey. Pediatr Int 2010;52:447-52.

8. Rasheed S, Abdelmonem A, Amin M. Adolescent pregnancy in Upper Egypt. Int J Gynaecol Obstet 2011;112:21-4.

9. Thaithae S, Thato R. Obstetric and perinatal outcomes of teenage pregnancies in Thailand. J Pediatr Adolesc Gynecol 2011;24:342-6.

10. Raatikainen K, Heiskanen N, Verkasalo PK, Heinonen S. Good outcome of teenage pregnancies in high-quality maternity care. Eur J Public Health 2006;16:157-61.

11. Mukhopadhyay P, Chaudhuri RN, Paul B. Hospital-based perinatal outcomes and complications in teenage pregnancy in India. J Health Popul Nutr 2010;28:494-500.
12. Edirne T, Can M, Kolusari A, Yildizhan R, Adali E, Akdag B. Trends, characteristics, and outcomes of adolescent pregnancy in eastern Turkey. Int J Gynaecol Obstet 2010;110:105-8.

13. Shrim A, Ates S, Mallozzi A, et al. Is young maternal age really a risk factor for adverse pregnancy outcome in a canadian tertiary referral hospital? J Pediatr Adolesc Gynecol $2011 ; 24: 218-22$.

14. Hacettepe Üniversitesi Nüfus Etütleri Enstitüsü. 2018 Türkiye Nüfus ve Sağlık Araştırması. Hacettepe Üniversitesi Nüfus Etütleri Enstitüsü, T.C. Cumhurbaşkanlığı Strateji ve Bütçe Başkanlığı ve TÜBiTAK, Ankara, Türkiye. 2019. Available from: http://www.hips.hacettepe.edu.tr/tnsa2018/rapor/ TNSA2018_ana_Rapor.pdf Accessed June 28, 2020.

15. Sultan Kavuncuoğlu, Emel Altuncu, Mehmet Gökhan Ramoğlu et al. Demographic distribution of all neonates born in our unit in a year, mortality and morbidity results. Available from: https://doi.org/10.1111/ped.13012. JOOP Derg 2010;2:106-15. 